\title{
COLLECTION, IDENTIFICATION, MOLECULAR CHARACTERIZATION, AND ANTIOXIDANT ACTIVITY OF NON-GILLED MUSHROOMS COLLECTED FROM NORTH WESTERN HIMALAYAS
}

\author{
SHAVETA SINGH, ASTHA TRIPATHI* \\ Department of Biotechnology, Shoolini University, Solan, Himachal Pradesh, India. Email: asthatripathi4u@gmail.com
}

Received: 21 May 2018, Revised and Accepted: 16 June 2018

\begin{abstract}
Objective: The objective of present research deals with collection, taxonomic, molecular taxonomy characterization, and antioxidant activity of wild non-gilled mushrooms sample collected from North Western Himalayas.

Methods: The wild non-gilled mushroom samples were characterized for micro, morphological properties, and molecular identification. 1,1 diphenylpicrylhydrazyl (DPPH), nitric oxide $\left(\mathrm{NO}_{2}\right)$, hydrogen peroxide $\left(\mathrm{H}_{2} \mathrm{O}_{2}\right)$, and free radical scavenging assay were used to evaluate the antioxidant properties of selected wild non-gilled mushrooms.

Results: The obtained results revealed that on the basis of microscopic and morphological identification all the four non-gilled mushrooms samples were tentatively identified as 2/15 (Auricularia sp.1), 6/15 (Auricularia sp.2), 32/15 (Ganoderma sp.), and 132/15 (Trametes sp.). The colony, mycelial, and basidiospore morphology of fungal isolate were evidence of Basidiomycetes family. All these four non-gilled mushrooms were sequenced. Sequences were submitted to National Center for Biotechnology Information (NCBI), and their accession number was MF770159 (2/15), MF774107 (6/15), MF770158 (32/15), and MF770160 (132/15). The phylogenetic analysis of 18S ribosomal deoxyribonucleic acid (18S rDNA) sequence of four non-gilled mushrooms was compared with other species and identified as Auricularia polytricha, Ganoderma lucidum, Auricularia auricula-judae, and Trametes elegans. The four non-gilled mushrooms extract exhibited $\mathrm{DPPH}, \mathrm{NO}_{2}$, and $\mathrm{H}_{2} \mathrm{O}_{2}$ free radical scavenging activities. G. lucidum methanolic extract has the highest effect on free radicals in comparison to hexane effect.
\end{abstract}

Conclusion: All the isolated four non-gilled mushrooms showed good antioxidant potential, and it can be concluded that these mushrooms are not only consumed but also have a wide range of medicinal properties which must further explode for future use.

Keywords: Non-gilled mushrooms, Phylogenetic tree, 18S r deoxyribonucleic acid, Antioxidant activity.

(C) 2018 The Authors. Published by Innovare Academic Sciences Pvt Ltd. This is an open access article under the CC BY license (http://creativecommons. org/licenses/by/4. 0/) DOI: http://dx.doi.org/10.22159/ajpcr.2018.v11i10.27423

\section{INTRODUCTION}

Mushroom belongs to a cluster of plants recognized as fungus. These are unit of natural ecosystems that have an essential role in the healthmaintaining process. Medicinal mushrooms are either collected from nature or cultivated. They introduced a lot of conferments especially in the consumption of food, in bioremediation, in a cure of diseases, antioxidant, and therapeutic diseases [1]. Antioxidants are compounds which terminate the action of free radicals, thereby protecting the body from oxidative damages [2]. These free radicals are independent chemicals with one or more unpaired electrons and are responsible for biological injury and contribute too many non-communicable diseases [3]. They are constantly formed in the human body during energy production, in the mitochondrial electron transport chain, phagocytizes, arachidonic acid metabolism, ovulation, fertilization, and in xenobiotic metabolism [4]. Ganoderma and Trametes species were studied for the screening of their therapeutic activities. These studies have shown the enormous pharmacological potential of these mushrooms especially for the management of various types of cancers. One of the most accepted possible mechanisms behind anticancer effects has been suggested to be the free radical scavenging activity. Free radicals such as reactive oxygen species (ROS) and reactive nitrogen species are mainly implicated in deoxyribonucleic acid (DNA) damage ultimately leading to uncontrolled cell proliferation. In the living system, nature has provided an endogenous defense mechanism as antioxidants which scavenge the harmful free radicals [5]. The consumption of dietary antioxidants would help to prevent free radical oxidative damage by inhibiting the initiation step or interrupting the propagation step of oxidation damage [6]. Natural antioxidants are characterized into plant and fungal extracts such as spices (rosemary, thyme, marjoram, oregano, sage, basil, pepper, clove, cinnamon, and nutmeg), flavonoids, ubiquinol (fully reduced form of coenzyme Q10), glutathione, zinc (Zn), selenium (Se), Vitamin A (including carotenoids), Vitamin C, and Vitamin E (including tocopherols and tocotrienols) [7]. Synthetic phenolic antioxidants include butylated hydroxyanisole, butylated hydroxytoluene, and others, for example, propyl gallate, and tert-butyl hydroquinone, ethoxyquin that all effectively inhibit oxidation [8]. Many researchers were studied that vitamins and polyphenols from planted sources including fruits, vegetables, grains, roots, tea, coffee, and the wine showed good antioxidant activities, and could protect mitochondria from dysfunction and apoptosis. Recently, it was found that wild mushrooms possessed vitamins and polyphenol compounds and exhibits strong antioxidant activities [9]. Therefore, it is necessary to find new potent antioxidants from other mushroom sources. The present study was undertaken to collect, to identify along with the molecular characterization of non-gilled mushrooms and to determine their effects as antioxidant compounds.

\section{METHODS}

Collection of samples

Fruiting body of four non-gilled mushrooms was collected from the North Western Himalayas and marked as collection number 2/15, 6/15, $32 / 15$, and $132 / 15$. These fruiting bodies were taken to the laboratory in sterile polybags. Each sample after cleaning with sterile water was cut across the pileus region with the help of sterilized blade to obtain bits (1-2 mm) of tissue, which was dipped in $0.1 \%$ mercuric chloride solution using sterile forceps for 10-15 s. Then, bits were transferred on to the plates of malt extract agar (MAE). 
Macroscopic and microscopic identification

The identification of the fruiting body of non-gilled mushrooms was based on macroscopic traits such as shape, size, a color of pileus, presence or absence of stripe and microscopic traits spores, and clamp connection.

\section{Molecular identification}

The pure fungal cultures were subcultured under sterile conditions in $250 \mathrm{~mL}$ flasks containing $100 \mathrm{~mL}$ of malt extract broth at $27^{\circ} \mathrm{C}$ for 8 days. The growing mycelial in MEA was then filtered through Whatman filter paper No.1 and used for DNA extraction.

\section{Isolation of genomic DNA}

Total DNA was extracted according to the methods described by Rajesh et al. and Moncalvo et al. [10,11] with some modification. A mass of $150 \mathrm{mg}$ of biomass was suspended in $500 \mu \mathrm{L}$ of extraction buffer (200 mm tris aminomethane hydrochloride (Tris-HCl), pH 8.0, $100 \mathrm{~mm}$ sodium chloride $(\mathrm{NaCl}), 25 \mathrm{~mm}$ ethylenediaminetetraacetic acid (EDTA), $0.5 \%$ sodium dodecyl sulfate, and vortexes and incubated at $65^{\circ} \mathrm{C}$ in warm water bath for $25 \mathrm{~min}$. Afterward, the samples were cooled on ice for $5 \mathrm{~min}$. The resulting suspension was extracted with $0.5 \mathrm{~mL}$ of phenol: $0.5 \mathrm{~mL}$ of chloroform:isoamyl alcohol (24:1) by vortexing for $1 \mathrm{~min}$ then tubes were incubated for $15 \mathrm{~min}$ at room temperature and followed by centrifugation at $12,000 \mathrm{rpm}$ for $25 \mathrm{~min}$ in a microcentrifuge. The upper phase was transferred to a new Eppendorf tube. Then, $350 \mu \mathrm{L}$ chloroform:isoamyl alcohol (24:1) was added to this Eppendorf tube, mixed by gently inverting and spun at $12,000 \mathrm{rpm}$ for $10 \mathrm{~min}$. The genomic DNA was precipitated from the supernatant by adding 0.54 volume of isopropanol and incubated overnight then the supernatant was discarded. The nucleic acid pellet was washed using $70 \%$ ethanol, air dried and resuspended in $50 \mu \mathrm{L}$ of TE buffer $(10 \mathrm{~mm}$ Tris- $\mathrm{HCl}, \mathrm{pH}$ 8.0, and $1 \mathrm{~mm}$ EDTA). Then, DNA samples were stored at $20^{\circ} \mathrm{C}$.

\section{Extracted genomic DNA by agarose gel electrophoresis}

Tris-acetate-ethylene (TAE) diamine tetraacetic acid buffer was prepared. For this, $500 \mathrm{mg}$ of agarose was dissolved in $50 \mathrm{~mL}$ of $\times 0.5 \mathrm{TAE}$ working buffer prepared from $\times 50$ TAE stock solution $(240 \mathrm{~g}$ Tris base, $57.1 \mathrm{~mL}$ glacial acetic acid $100 \mathrm{~mL} \mathrm{0.5} \mathrm{M} \mathrm{EDTA).} \mathrm{Then,} \mathrm{the} \mathrm{mixture} \mathrm{was}$ heated up to agarose gel was dissolved. The agarose solution was cooled at $60^{\circ} \mathrm{C}$ after that $10 \mathrm{mg} / \mathrm{mL}$ ethidium bromide solution was added to the buffer (concentration of $0.5 \mu \mathrm{g} / \mathrm{mL}$ ). The solution was poured into the gel. The gel casting tray was sealed on both sides with tape and agarose was poured into the tray. The comb was placed in the gel and allowed to solidify at room temperature for 30-35 min. After solidification, the comb and the tape were removed. The gel tray was placed in the electrophoresis tank. A volume of $2 \mu \mathrm{L}$ DNA, $1 \mu \mathrm{L}$ tracking dye, and $7 \mu \mathrm{L}$ distilled water were mixed well and loaded in well with the help of micropipette. The gel was run at 50 volts for $45-60 \mathrm{~min}$. The electrophoresis was stopped when the samples had run the required distance and gel was visualized under the ultraviolet (UV) illuminator and photographed under UV rays.

\section{Polymerase chain reaction (PCR) amplification}

5.8 S rRNA gene was amplified by PCR using universal primer pair of $0.5 \mu \mathrm{M}$ of each primer, i.e. ITS1 (5'- TCCGGTAGGTGAACCTGCGG-3') and ITS4 (5'-TCCTCCGCTTATTGATATGC -3'). The $50 \mu \mathrm{L}$ reaction mixture contained the following components: $1 \mu \mathrm{L}$ template DNA, $\times 1$ PCR buffer, 2.5 units of Taq DNA polymerase, $0.2 \mathrm{mM}$ of deoxyribonucleotide triphosphate mixture, $1.5 \mathrm{mM}$ magnesium chloride $\left(\mathrm{Mgcl}_{2}\right)$, and sterile water $31.5 \mu \mathrm{L}$. Mix the contents for $1-2 \mathrm{~s}$ thoroughly. The tubes were placed in thermocycler block. The PCR program was carried out in the following manner of 30 cycles with an initial denaturation step at $94^{\circ} \mathrm{C}$ for $5 \mathrm{~min}$, followed by denaturation step at $94^{\circ} \mathrm{C}$ for $30 \mathrm{~s}$, annealing at $58^{\circ} \mathrm{C}$ for $30 \mathrm{~s}$, extension at $72^{\circ} \mathrm{C}$ for $1 \mathrm{~min}$, and final extension at $72^{\circ} \mathrm{C}$ for $2 \mathrm{~min}$. A volume of $5 \mu \mathrm{L}$ of PCR product with $5 \mu \mathrm{L}$ of loading dye was mixed and loaded on a $1.5 \%$ agarose gel and PCR product were resolved at $50 \mathrm{~V}$ for $45 \mathrm{~min}$. The gel was visualized under UV light and photographed under the gel doc imaging system.

\subsection{S rRNA Gene sequencing}

PCR product was sent to the Postgraduate Institute of Medical Education and Research (PGIMER), Chandigarh, for sequencing.

\section{Phylogenetic tree}

The 18rDNA nucleotide sequence was used to carry out Basic local alignment search tool (BLAST). BLAST of the obtained sequence was performed with a database of the gene bank. Based on maximum identity score first, 10 were selected and aligned using multiple alignment software program Clustal W. Distance matrix was generated using ribosomal database project database and the phylogenetic tree was constructed using Mega 6 software.

1,1 diphenylpicrylhydrazyl (DPPH) free radical scavenging activity The DPPH free radical scavenging activity assays were performed according to the procedure described by Hung and Morita, Tibuhwa $[12,13]$ with some modification. Ascorbic acid was used as a standard control. A measure of $0.5 \mathrm{~mL}$ of the extract was mixed with $0.5 \mathrm{~mL}$ of $0.1 \mathrm{Mm}$ methanolic solutions containing DPPH radical that is very stable. The mixture was shaken vigorously and left to stand for $30 \mathrm{~min}$ in the dark at room temperature. The reaction mixture was determined at $515 \mathrm{~nm}$ against blank. A lower absorbance represents a higher DPPH scavenging activity. The percentage of DPPH radical scavenging activity was calculated using the following equation:

DPPH free radical scavenging activity $(\%)=(1-\mathrm{As} / \mathrm{Ac}) \times 100$

$\mathrm{Ac}=$ absorbance of control containing DPPH solution

As $=$ absorbance of extract solution containing DPPH

Nitric oxide $\left(\mathrm{NO}_{2}\right)$ radical scavenging activity

The analog of the extract of macrofungi with $\mathrm{NO}_{2}$ was determined by nitrite detection method. $\mathrm{NO}_{2}$ ions were produced using the Griess Illosvoy reaction. $2 \mathrm{~mL}$ of $10 \mathrm{mM}$ sodium nitroprusside in $0.5 \mathrm{~mL}$ phosphate buffer saline ( $\mathrm{pH} 7.4$ ) was mixed with $0.5 \mathrm{~mL}$ of extracts and the mixture was incubated at $25^{\circ} \mathrm{C}$ for $5 \mathrm{~h}$. After the incubation of $5 \mathrm{~h}$ at $37^{\circ} \mathrm{C}, 0.5 \mathrm{~mL}$ of Griess reagent ( $\alpha$-naphthyl ethylenediamine dihydrochloride) $0.1 \%$ in water and sulfanilic acid $1 \%$ in phosphoric acid $\left(\mathrm{H}_{3} \mathrm{PO}_{4}\right)$, and $5 \%$ was added into $1.0 \mathrm{~mL}$ sulfanilic acid. The UV absorbance was measured at $546 \mathrm{~nm}$. The $\mathrm{NO}_{2}$ radicals scavenging activity was calculated according to the following equation [14].

\section{Hydrogen peroxide $\left(\mathrm{H}_{2} \mathrm{O}_{2}\right)$ free radical scavenging activity}

$\mathrm{H}_{2} \mathrm{O}_{2}(40 \mathrm{mM})$ solution was prepared in phosphate buffer (7.4 pH). The absorption at $230 \mathrm{~nm}$ was measured by a spectrophotometer to determine the concentration of the $\mathrm{H}_{2} \mathrm{O}_{2}$. The extracts $(10-100 \mu \mathrm{g} / \mathrm{mL})$ were added to the $\mathrm{H}_{2} \mathrm{O}_{2}$ solution. After 10 min of incubation, the absorbance was determined at $230 \mathrm{Nm}$. Phosphate buffer was used as a blank. Ascorbic acid was used as standard curve $[15,16]$.

\section{RESULTS}

\section{Identification}

Four non-gilled fruiting bodies were identified on the basis of taxonomic and molecular identification.

\section{Macroscopic identification}

Fruiting bodies of non-gilled mushrooms were based on microscopic traits such as traits, size, and color of pileus, and presence or absence of stripe (Table 1 ).

\section{Microscopic identification}

Four pure cultures were obtained on MEA. These four pure cultures were carried out for microscopic study which included clamp connection and spores (Fig. 1). On the basis of macroscopic and microscopic identification, the samples were tentatively identified 2/15 (Auricularia sp.1), 6/15 (Auricularia sp.2), 32/15 (Ganoderma sp.), and 132/15 (Trametes sp.). 
Table 1: Morphological identification of non-gilled mushrooms fruiting bodies

\begin{tabular}{|c|c|c|}
\hline Sample & Fruiting bodies & Morphological identification \\
\hline $2 / 15$ & & $\begin{array}{l}\text { 2-4 cm cup or fan-shaped, elastic, and gelatinous. Creamish brown, lower surface is gelatinous, brown color, } \\
\text { upper surface is soft, silky, pinkish brown, and rubber-like body }\end{array}$ \\
\hline $6 / 15$ & 1 & $\begin{array}{l}\text { Fruiting bodies were } 3-6 \mathrm{~cm} \text {, fan-shaped, smooth curved, elastic, gelatinous, and upper surface is dark brown } \\
\text { in color or lower surface is brown in color, stripe is absent, Gills absent }\end{array}$ \\
\hline $32 / 15$ & & $\begin{array}{l}\text { Fruiting bodies were large. Cap: Circular or semicircular, kidney-shaped } 5-8 \mathrm{~cm} \text { broad. Upper surface smooth } \\
\text { or tough, orange-red or reddish black in center, light yellow toward the margin, the cap is tough or woody. } \\
\text { Stalk } 6-8 \mathrm{~cm}\end{array}$ \\
\hline & & $\begin{array}{l}\text { Short stripe such as base, pileus up to } 11 \mathrm{~cm} \text { wide, woody, upper surface is dark brown, and inner surface is } \\
\text { creamish, color, and smooth }\end{array}$ \\
\hline
\end{tabular}

2/15: Auricularia auricular-judae, 6/15: Auricularia polytricha, 32/15: Ganoderma lucidum, 132/15: Trametes elegans
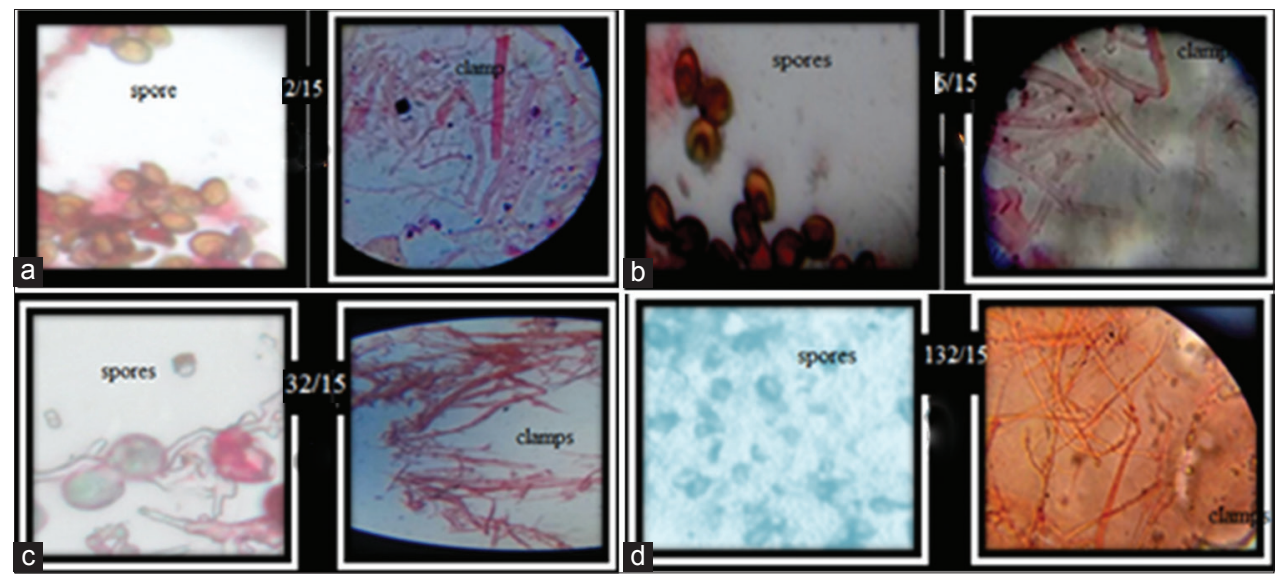

Fig. 1: Endospore structure and clamp connection (a) 2/15: Auricularia sp.1, (b) 6/15: Auricularia sp.2, (c) 32/15: Ganoderma sp., and (d) 132/15: Trametes sp.

\section{Molecular identification}

In the present study, DNA was extracted from the fungal mycelium of four non-gilled mushrooms isolates was amplified with ITS 1 and ITS 4 primers. The size of the DNA of four mushrooms samples was approximately $500 \mathrm{bp}$ (Fig. 2). PCR products were sent to PGMIER Chandigarh, for sequencing. 18S DNA nucleotide sequence was obtained by sequencing the PCR product shown in Table 2 and analyzed for BLAST. According to the blast, samples $(6 / 15,32 / 15,2 / 15$, and $132 / 15)$ they mostly resembled with Auricularia auricula-judae (2/15), Auricularia polytricha (6/15), Ganoderma lucidum (32/15), and Trametes elegans (132/15). The aligned nucleotide sequence of samples was submitted to NCBI and nucleotide sequence is provided with gene bank accession no. MF770159, MF774107, MF770158, and MF770160. The phylogenetic tree was constructed (Fig. 3) of all the four isolated non-gilled mushrooms and revealed that all the samples are closely related fungi.

\section{DPPH free radical scavenging activity}

The antioxidant activity of methanolic and hexane extracts was expressed as inhibitory concentration $\left(\mathrm{IC}_{50}\right)$ values of DPPH. Both the extracts of $G$. lucidum showed good $\mathrm{IC}_{50}$ value. However, the methanolic extract of G. lucidum showed the higher effect on DPPH having $\mathrm{IC}_{50}$ value $140.85 \pm 0.64$ in comparison to hexane extract of $G$. lucidum having IC $_{50}$ value $429.9 \pm 2.16$ followed by $A$. polytricha having $\mathrm{IC}_{50}$ value $203.52 \pm 1.10$ for methanolic extract and $587.53 \pm 0.92$ for hexane extract. Both the extracts of $T$. elegans having lower $\mathrm{IC}_{50}$ value $287.08 \pm 2.53$ for methanol extract and $1079.31 \pm 2.15$ for hexane extract as shown in Tables 3 and 4 .

\section{$\mathrm{NO}_{2}$ free radical scavenging activity}

$\mathrm{NO}_{2}$ scavenging effect increased with the increasing concentrations of extract. Our study suggests that all the extracts inhibited $\mathrm{NO}_{2}$ production. $\mathrm{NO}_{2}$ having $\mathrm{IC}_{50}$ value $365.16 \pm 0.23$ of G. lucidum in the methanolic extract was highest in compared to hexane extract of G. lucidum $584.76 \pm 0.32$ and lower in $T$. elegans having $\mathrm{IC}_{50}$ value $667.02 \pm 1.99$ for methanol extract and $1589.85 \pm 1.63$ for hexane extract as shown in Tables 3 and 4.

\section{$\mathrm{H}_{2} \mathrm{O}_{2}$ free radical scavenging activity}

Tables 3 and 4 showed the $\mathrm{H}_{2} \mathrm{O}_{2}$ scavenging effect by measuring the inhibition of the degradation of 2 -deoxyribose by free radical generated 


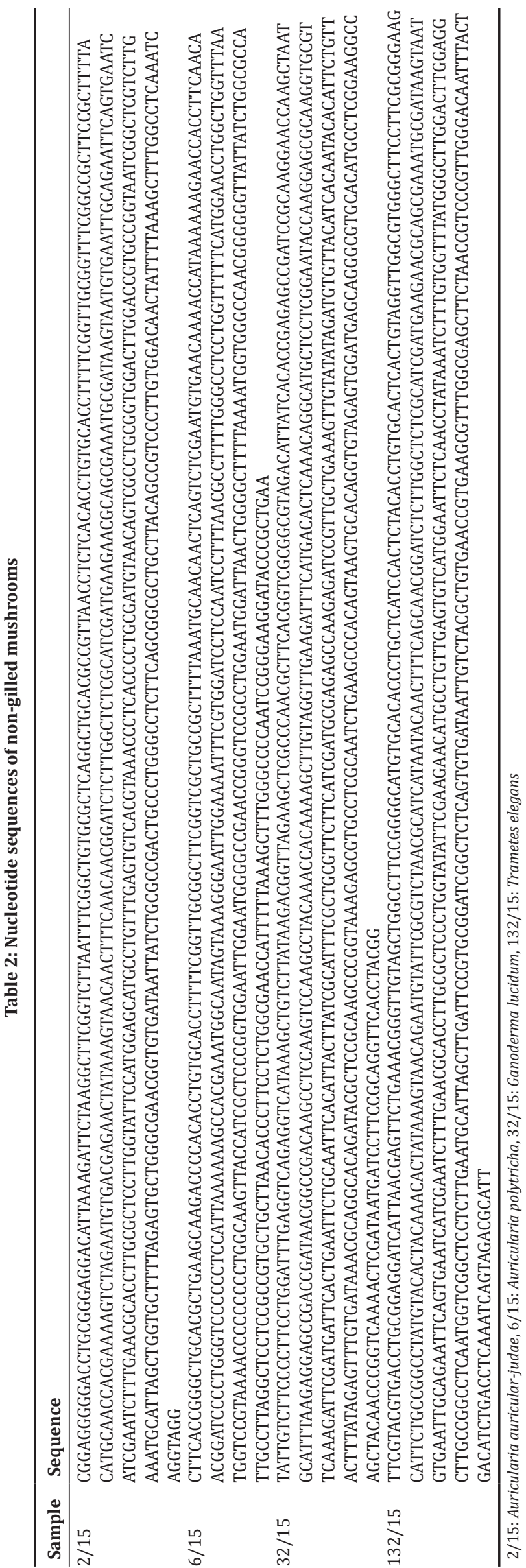

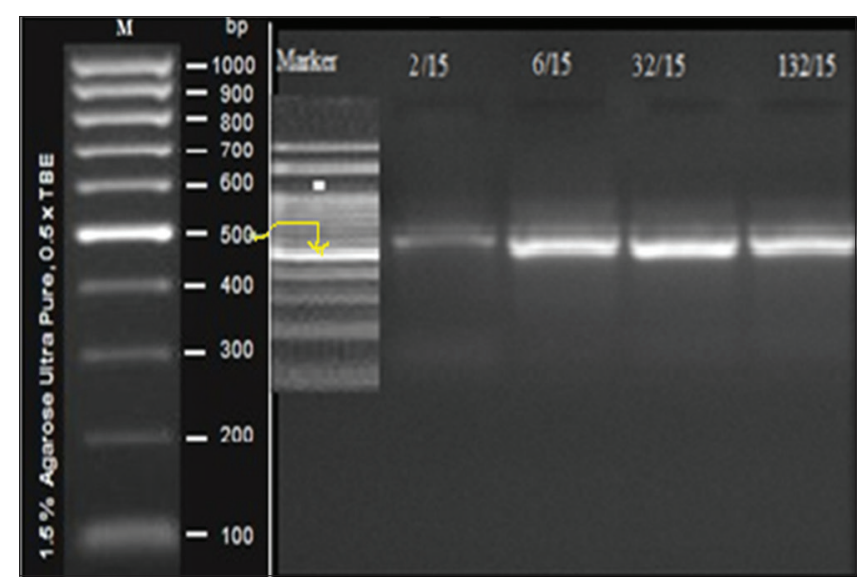

Fig. 2: 18S Polymerase chain reaction replicon of 2/15: Auricularia auricula-judae, 6/15: Auricularia polytricha, 32/15: Ganoderma lucidum, and 132/15: Trametes elegans

by Fenton reaction. In the present study, it was observed that effect on $\mathrm{H}_{2} \mathrm{O}_{2}$ was higher having $\mathrm{IC}_{50} 368.46 \pm 1.26$ in G. lucidum of methanolic extract and lower $1145.45 \pm 1.11$ in T. elegans of hexane extract.

\section{DISCUSSION}

Antioxidants donate an electron to stabilize a free radical. When a free radical is invalidated, it is not capable of damaging our cells. Today science is quite anxious for natural scavengers from natural sources to fight as defense mechanisms against various diseases and ailments. Antioxidants escort our body against free radicals and mushrooms are a rich source of these antioxidants.

DPPH is a stable free radical scavenger with an absorption band around 515-528 nm, that accepts an electron or hydrogen radical to become a stable diamagnetic molecule and thus DPPH reagent used for evaluation of antioxidant activity of compounds. Antioxidants reduce the DPPH radical to a yellow colored compound (DPPH), and the degree of the reaction will depend on the hydrogen donating ability of the compounds [17]. In the present study, results revealed that scavenging effects of methanol extracts and hexane extracts on DPPH radical increased with increased concentrations. However, methanol extracts of $G$. lucidum show higher scavenging activity on DPPH radical than hexane extracts. Another study also found that the Auricularia judae showed a high scavenging activity at $93.33 \%$ followed by Polyporus tenuiculus with $90.71 \%$ of methanolic extract [18]. However, the lowest effective concentration of $\mathrm{EC}_{50}$ has observed in A. judae $0.08 \mathrm{mg} / \mathrm{ml}$ showed strongest. Methanolic extracts from Tarchonanthus camphoratus and Agaricus blazei at $2.5 \mathrm{mg} / \mathrm{mL}$ showed excellent scavenging effects (96.3-99.1 and 97.1\%) [19]. According to Kamiyama et al. showed that Trametes versicolor of acetone extract showed highest scavenging activity at $54.9 \pm 0.1 \%$ at $500 \mu \mathrm{g} / \mathrm{mL}$ than methanol extract at $40.0 \pm 0.2 \%$ against DPPH radical [20]. Scavenging activity of medicinal mushrooms including G. lucidum, G. lucidum antler, and Ganoderma tsugae of methanolic extract exhibited a strong reducing power of $1.62,2.28$, and 2.38 at $4.0 \mathrm{mg} / \mathrm{mL}$ [21].

$\mathrm{NO}_{2}$ is an effective pleitropic inhibitor of physiological processes present in mammalian cells such as smooth muscles and an essential bioregulatory molecule required for neural signal transmission, immune response, control vasodilatation, and control of blood pressure [22]. $\mathrm{NO}_{2}$ is free radical that has an unpaired electron. $\mathrm{NO}_{2}$ in higher concentration can be a toxic product, peroxynitrite (ONOO-). Hence, inhibition of $\mathrm{NO}_{2}$ is must be done. Reducing the $\mathrm{NO}_{2}$ generation in the digestive tract was observed to be effective in preventing the reactions of nitrate with amines and amides to form carcinogenic nitrosamines and nitrosamides. Scavenging activity of G. lucidum extract of $\mathrm{NO}_{2}$ could play an essential role against nitrosamine mediated carcinogenesis [23]. The present study finds that all the four non-gilled 


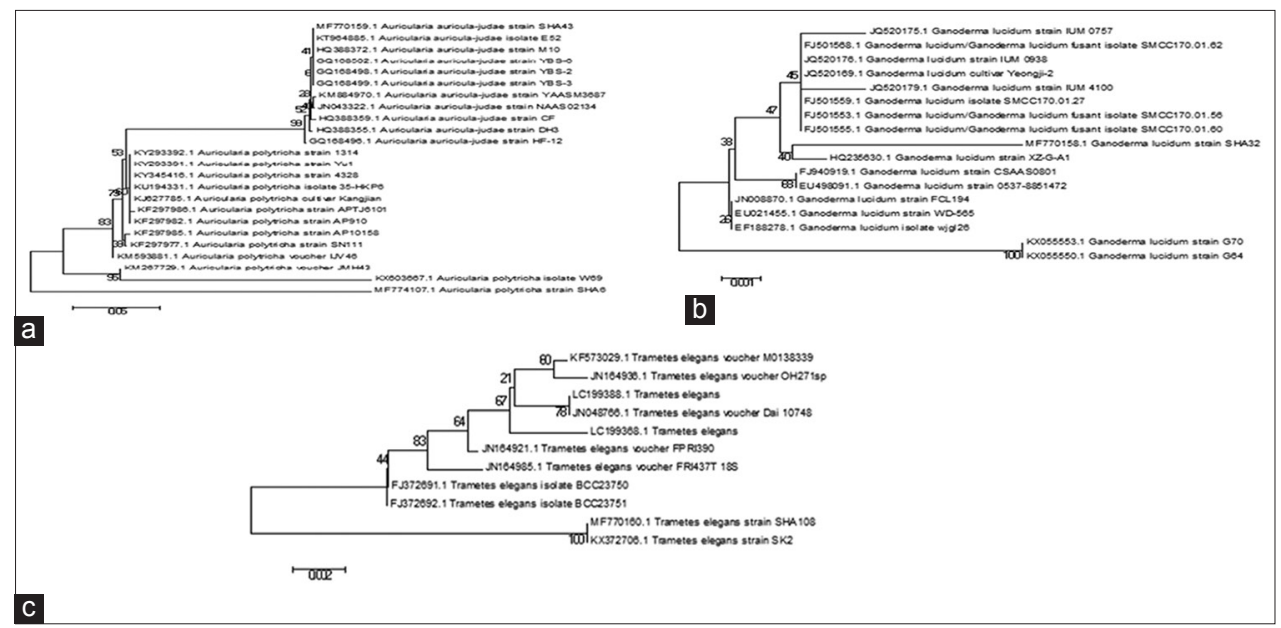

Fig. 3: Phylogenetic tree derived from partial 18S rDNA gene sequence of (a) Auricularia polytricha and Auricularia auricula-Judea, (b) Ganoderma lucidum, (c) Trametes elegans

Table 3: $\mathrm{IC}_{50}$ value of methanol extract of different non-gilled mushroom cultures for DPPH, $\mathrm{NO}_{2}$, and $\mathrm{H}_{2} \mathrm{O}_{2}$ free radical scavenging activity

\begin{tabular}{|c|c|c|c|}
\hline \multirow[t]{2}{*}{ Isolates } & \multicolumn{3}{|c|}{$\mathrm{IC}_{50}$ value $(\mathrm{mg} / \mathrm{mL})$ for the methanol extract } \\
\hline & $\mathrm{IC}_{50}$ (DPPH) & $\mathrm{IC}_{50}\left(\mathrm{NO}_{2}\right)$ & $\mathrm{IC}_{50}\left(\mathrm{H}_{2} \mathrm{O}_{2}\right)$ \\
\hline $\begin{array}{l}\text { Auricularia } \\
\text { auricula-judae }\end{array}$ & $245.72 \pm 1.02$ & $599.11 \pm 1.30$ & $828.38 \pm 0.54$ \\
\hline $\begin{array}{l}\text { Auricularia } \\
\text { polytricha }\end{array}$ & $203.52 \pm 1.10$ & $457.74 \pm 1.91$ & $457.74 \pm 1.91$ \\
\hline $\begin{array}{l}\text { Ganoderma } \\
\text { lucidum }\end{array}$ & $140.85 \pm 0.64$ & $365.16 \pm 0.23$ & $368.46 \pm 1.26$ \\
\hline $\begin{array}{l}\text { Trametes } \\
\text { elegans }\end{array}$ & $287.08 \pm 2.53$ & $667.02 \pm 1.99$ & $1089.5 \pm 0.41$ \\
\hline
\end{tabular}

Table 4: $\mathrm{IC}_{50}$ value of hexane extract of different non-gilled mushroom cultures for DPPH, $\mathrm{NO}_{2}$, and $\mathrm{H}_{2} \mathrm{O}_{2}$ free radical scavenging activity

\begin{tabular}{|c|c|c|c|}
\hline \multirow[t]{2}{*}{ Isolates } & \multicolumn{3}{|c|}{$\mathrm{IC}_{50}$ value $(\mathrm{mg} / \mathrm{mL})$ for the hexane extract } \\
\hline & $\mathrm{IC}_{50}(\mathrm{DPPH})$ & $\mathrm{IC}_{50}\left(\mathrm{NO}_{2}\right)$ & $\mathrm{IC}_{50}\left(\mathrm{H}_{2} \mathrm{O}_{2}\right)$ \\
\hline $\begin{array}{l}\text { Auricularia } \\
\text { auricula-judae }\end{array}$ & $793.63 \pm 2.45$ & $1006.02 \pm 1.86$ & $843.69 \pm 0.64$ \\
\hline $\begin{array}{l}\text { Auricularia } \\
\text { polytricha }\end{array}$ & $587.53 \pm 0.92$ & $915.38 \pm 1.03$ & $663.43 \pm 1.91$ \\
\hline $\begin{array}{l}\text { Ganoderma } \\
\text { lucidum }\end{array}$ & $429.9 \pm 2.16$ & $584.76 \pm 0.32$ & $514.29 \pm 0.41$ \\
\hline $\begin{array}{l}\text { Trametes } \\
\text { elegans }\end{array}$ & $1079.31 \pm 2.15$ & $1589.85 \pm 1.63$ & $1145.45 \pm 1.11$ \\
\hline
\end{tabular}

Values are means of triplicate determinations \pm standard deviation.

$\mathrm{IC}_{50}$ : Inhibitory concentration, DPPH: 2,2-diphenyl-1-picrylhydrazyl, $\mathrm{NO}_{2}$ : Nitric oxide, $\mathrm{H}_{2} \mathrm{O}_{2}$ : Hydrogen peroxide

mushrooms inhibited the $\mathrm{NO}_{2}$ production but methanol show more effectiveness in antioxidant activity than hexane extract. NO-scavenging dose-response curve of cold water, hot water, and methanolic extracts that exhibitory concentration 50 value for hot water 14 -fold greater than that of methanolic extract of Pleurotus squarrosulus [24]. The chloroform extract of G. lucidum showed scavenging activity of the extract $\left(\mathrm{IC}_{50} 21.6 \pm 1.5 \mu \mathrm{g} / \mathrm{mL}\right.$ ) against $\mathrm{NO}_{2}[23]$.

$\mathrm{H}_{2} \mathrm{O}_{2}$ is a biologically material, non-radical oxidizing species may be formed in tissues through oxidative processes. $\mathrm{H}_{2} \mathrm{O}_{2}$ generates hydroxyl radicals $(\bullet \mathrm{OH})$ resulting in the initiation and propagation of lipid peroxidation. The ability of the extracts to quench $(\bullet \mathrm{OH})$ seems to be directly related to the prevention of the lipid peroxidation [25]. Methanolic extract of Agaricus bisporous showed good $\mathrm{H}_{2} \mathrm{O}_{2}$ scavenging activity, but it was less effective than standard ascorbic acid and appears to be a moderate scavenger of active, reactive oxygen species [26].

The present study showed that both methanolic and hexane extracts of four non-gilled mushrooms mycelial cultures showed free radical scavenging activity. Methanolic and hexane extracts showed maximum scavenging activity in G. lucidum. However, in comparison to hexane the methanolic extract shows more scavenging activity.

\section{CONCLUSION}

According to this study, these four non-gilled mushrooms may be beneficial to the antioxidant protection system of the human body against oxidative damage. Both the methanolic and hexane extracts used against different free radical systems showed excellent radical scavenging potential which is indicative of their antioxidant activity. This study innovated the potential antioxidative role of non-gilled mushrooms in free radical systems. G. lucidum could evolve to be a better source of antioxidants. Therefore, these non-gilled mushrooms can be used as an easily available source of natural antioxidants and as promising food supplements in an effort to curtail nutrition insecurity.

\section{ACKNOWLEDGMENT}

The authors express their sincere thanks to the Department of Biotechnology, Shoolini University of Biotechnology and Management Sciences, Solan, India, for support and corporate facilities.

\section{AUTHOR'S CONTRIBUTIONS}

The experimental part of the work and writing of the manuscript was done by the first author Shaveta Singh under the supervision of author Dr. Astha Tripathi.

\section{CONFLICTS OF INTEREST}

The authors declare that they have no conflicts of interest.

\section{REFERENCES}

1. Wan BA, Bodha RH, Wani AH. Nutritional and medicinal importance of mushrooms. J Med Plants Res 2010;4 Suppl 24:2598-604.

2. Gan CH, Nurul-Amira B, Asmah R. Antioxidant analysis of different types of edible mushrooms (Agaricus bisporous and Agaricus brasiliensis). Int Food Res J 2013;20 Suppl 3:1095-102

3. Kumari M, Giridhar S, Khanna PK. In vitro and in vivo antioxidant potentials of Pleurotus florida in experimental animals. Mushroom Res 
2004;13 Supp 1:21-6.

4. Halliwell B, Gutteridge J. Free Radicals in Biology and Medicine. $4^{\text {th }}$ ed. Oxford, UK: Oxford University Press; 2007.

5. Sheikh IA, Vyas D, Lone R, Singh V. Ganoderma lucidum and Trametes hirsute as potent antioxidant in free radical system in in vitro. World $\mathrm{J}$ Pharm Pharm Sci 2000;4 Suppl 5:1695-710.

6. Olajire A, Azeez L. Total antioxidant activity, phenolic, flavonoid and ascorbic acid contents of Nigerian vegetables. Afr J Food Sci Tech 2011;2 Suppl 2:22-9.

7. Brewer MS. Natural antioxidants: Sources, compounds, mechanism of action, and potential applications. Comp Rev Food Sci Food Saf 2011;10:221-47.

8. Venkatesh R, Sood D. Review of the Physiological Implications of Antioxidants in Food Interactive Qualifying. Worcester, MA, USA: Project Report; Faculty of the Worcester Polytechnic Institute; 2009. p. 1-72.

9. Zhang YJ, Gan RY, Li S, Zhou Y, Li AN, Xu DP, et al. Antioxidant phytochemicals for the prevention and treatment of chronic diseases. Molecules 2015;20:21138-56.

10. Rajesh K, Dhanasekaran D, Panneerselvam A. Isolation and taxonomic characterization of medicinal mushroom Ganoderma spp. Acad J Micro Res 2014;2 Suppl 2:61-70.

11. Moncalvo JM, Wang H, Hseu RS. Gene phylogeny of the Ganoderma lucidum complex based on ribosomal DNA sequences. Comparison with traditional taxonomic characters. Mycol Res 1995;99:1489-99.

12. Hung PV, Morita N. Distribution of phenolic compounds in the graded flours milled from whole buckwheat grains and their antioxidant capacities. Food Chem 2009;109:325-31.

13. Tibuhwa DD. A comparative study of antioxidant activities between fresh and dry mushrooms in the genera Cantharellus and Afrocantharellus from Tanzania. Food Nut Sci 2014;5:212-21.

14. Sheikh IA, Vyas D, Ganaie MA, Dehariya K, Singh V. HPLC determination of phenolics and free radical scavenging activity of ethanolic extracts of two Polypore mushrooms. Int J Pharma Pharma Sci 2014;6 Suppl 1:679-84
15. Khaled-khodjaa N, Boulekbache-Makhloufb L, Madani K. Phytochemical screening of antioxidant and antibacterial activities of some Laminaceae. Ind Cr Pro 2014;61:41-8.

16. Jose S, Radhamany PM. In vitro antioxidant activities, total phenolics and flavonoid of wild edible mushroom Macrolepiota mastoidea (fr.) singer. Int J Pharm Pharm Sci 2013;5 Suppl 2:161-6.

17. Russell R, Paterson M. Ganoderma-a therapeutic fungal factory phytochemistry. J Phytochem 2006;67:1985-2001.

18. Hussein JM, Tibuhwa DD, Mshandete AM, Kivaisi AK. Antioxidant properties of seven wild edible mushrooms. J Appl Microb 2015;9 Suppl 9:471-9.

19. Huang LC. Antioxidant Properties and Polysaccharide Composition Analysis of Antrodia camphorate and Agaricus blazei. Master's Thesis, National Chung-Hsing University, Taichung, Taiwan; 2000.

20. Kamiyama M, Horiuchi M, Umano K, Kondo K, Otsuka Y, Shibamoto T. Antioxidant/anti-inflammatory activities and chemical composition of extracts from the mushroom Trametes versicolor. Int J Nutr Food Sci 2013;2 Suppl 2:85-91

21. Mau JL, Lin HC, Chen CC. Antioxidant properties of speciality medicinal mushrooms. J Agric Food Chem 2002a;50:6072-7.

22. Ray G, Hussain SA. Oxidants and antioxidants and carcinogenesis. Indian J Exp Biol 2002;40:1214

23. Soniamol J, Baby S, Varughese G, Thozhuthumparambal PS, Kainoor KJ. Antioxidative and antiinflammatory activities of the chloroform extract of Ganoderma lucidum. Ind Sci Pharm 2009;77:111-21.

24. Pal J, Ganguly S, Tahsin KS, Acharya K. In vitro free radical scavenging activity of wild edible mushroom, Pleurotus squarrosulus (Mont.) Singer. Ind J Exp Bio 2010;47:1210-8.

25. Park YS, Heo BG, Ham KS, Kang SG, Gorinstein S. Analytical determination of bioactive compounds as an indication of fruit quality. JAOAC 2012;95 Suppl 6:1725-32.

26. Giannenas I, Tsalie E, Chronis EF, Mavridis S, Tontis D, Kyriazakis I. Consumption of Agaricus bisporus mushroom affects the performance, intestinal microbiota composition and morphology, and antioxidant status of turkey poults. Ani Feed Sci Tech 2011;165 3 Suppl 4:218. 